\title{
Does Marketing Success Factors Influence Private College Admission? Evidence From Malaysia
}

\author{
Zalina Zainudin ${ }^{1}$, Mohd Faiq Bin Abdul Fattah ${ }^{1} \&$ Sheikh Muhamad Hizam Sheikh Khairudin ${ }^{1}$ \\ ${ }^{1}$ University of Kuala Lumpur Business School, Malaysia \\ Correspondence: Zalina Zainudin, University of Kuala Lumpur Business School, Malaysia.
}

Received: April 30, 2019

Accepted: May 30, 2019

Online Published: June 11, 2019

doi:10.5430/ijfr.v10n5p440

URL: https://doi.org/10.5430/ijfr.v10n5p440

\begin{abstract}
Private colleges are predicted to be presented with many opportunities as well as challenges in the coming years. Admission pressures become one of the challenges face by most of Private Colleges in Malaysia. Lacking of marketing mix strategy are claimed to contribute to this admission pressure. This study was conducted firstly, to determine the relationship between marketing success factors (Price, Place, Product, Promotion, People, Process, Physical Evidence, Partnership, Publication and Conference, Presentation and Extracurricular Program) with the marketing mix strategy of private colleges. Secondly, to determine the relationship between Marketing Mix Strategy with Private College Admission. Similarly, in this study, these 11Ps are the success factors of private college marketing mix strategy in influencing student to study in private colleges. Structural Equation Model (SEM) is conducted to estimate the effects of the main construct on its subcontracts, exogeneous and endogenous variables and its significant relationship. The result found the factors with the highest percentage of variation in contributing to Marketing Mix Strategy are Promotion, Product, Place, Price, Process, Partnership, Presentation, People, Physical Evidence, Publication and Conference and lastly Extracurricular Program. Thus, concluding that 11Ps Marketing Mix Strategy has a significant relationship with Private College Admissions. National private colleges can create a strategy based on the marketing mix strategy in competing for students. The study area is Malaysia, and it was conducted over a sample of 366 executive and marketing officers as the respondents.
\end{abstract}

Keywords: 11Ps extended marketing mix strategy, private college, student admission

\section{Introduction}

The Ministry of Higher Education Malaysia (MOHE) has an initiative known as the Higher Education Blueprint 2012-2025 to change the local nationalistic perspective to a broader look of the globalized world to improve the national higher education by cementing its position as a major player in the region and the world (Abdul, 2010). Private colleges are involved in reforming better educational system to attract more students to study at private colleges in the country. College admission is the process through which students are accepted to enter into any private college, open for prospective students several times in an academic year. Marketing plays a vital role in private college admission to attract students of different backgrounds of qualifications, interests and skills for all undergraduate programs, thus, influencing the admission rate. The 7Ps of marketing mix elements (product, price, place, promotion, people, process, and physical evidence) are the common marketing success factors in the higher education industry (Abdul, 2010). Extended marketing mix elements (partnership, publication \& conference, presentation and extracurricular program) will further extend the success. These are marketing success factors influencing the reasons why local and international students choose to attend a particular college.

\subsection{Problem Statement}

Private colleges are harnessing their full potential and the marketing strategy in maximizing the number of local and international students and lacking sustainable and competitive business model which does not improve student admission results. Unfavorable perception hurts private colleges' publicity and image, severely impacting growth in student admission. A wide range of studies has been conducted. However, there are still several gaps remaining in previous researches suggested for further study. There are still limitations in the previous researches on the generalization of its findings due to the differences in research context, background and methodology and importance to further research this topic due to globalization. Respondents in previous researches were the student population. Studies in the institutional context to investigate how the higher education institution successfully 
influences student admission is lacking. Previous studies did not cover all types of higher education institutions such as private colleges. Although it has found numerous factors in influencing student admission, these factors have different levels of importance and may be different from one place to another. Therefore, this research will determine the additional success factors that contribute to the success of private college in influencing student admission.

\section{Literature Review}

\subsection{Private College Admission}

Private higher education institutions have been given the autonomy to set their own criteria for student selection and the processing of applications is decentralized and accepted by individual colleges. In the free market, college admission ise facing matchs between the interests and skills of the applicants and the higher education programs and response to challenges such as intense competition, causing smaller applicant pool, a low number of qualified applicants, selective students, affordability, declining college-going rates and etcetera. Students will start with research, enquiry, shortlist of a few education institutions that are best for their desired programs and would understand the admission cycle before applying. Students would highly likely to attend a college that has a bundle of benefits or at least the most affordable ones even without financial aid (Asia Exchange, 2016).

\subsection{Relationship Between Marketing Mix Strategy and Student Admission}

The right marketing mix is the key ingredients to achieve the entry application goals in a course or program in an intake at a college (Awang, et al, 2012). In Malaysia's higher education context, there are substantial studies grounded by the marketing mix that have been conducted. Previous researches on several public universities in Malaysia such as Malaysia National University (UKM), University Of Malaya (UM), Universiti Utara Malaysia (UUM) and International Islamic University Malaysia (IIUM) on the graduate school towards pre-university students, local and international students, shows that, generally, there are varying significance levels of relationship of elements of marketing mix which are the product, promotion, place, people, price, process and physical evidence with student determinant of choice factors (Beiler, 2014). Studies in private higher education institutions such as Lim Kok Wing on the Enrollment Program over various students found a significant relationship between the same set of variables with choice of institutions, foundation of decision-making and determinant of enrolment.

\subsection{Theory of Extended Marketing Mix}

The 7P's Marketing Mix is the underpinning theory in this research. Also known as services marketing mix, it consists of a set of variables which are Product (PRO), Promotion (PROM), Price (PRI), Place (PLA), People (PEO), Process (PROC) and Physical Evidence (PE). There are many other variables that have been studied and regarded as the elements of marketing mix theorizing influential relationship with customer behavior and various marketing objectives set by higher educational institutions (Beiler, 2014). The 7P's marketing mix is the mostly found theory used in academic literatures. A study conducted on the preferences towards the selection of university in Indonesia among first-year students including international students found that all the 7P's marketing mix were considered by the students in making a choice. A study conducted in Spain proposed a new 13Ps marketing mix framework consisting of price, people, process, program, place, physical facilities, planned corporate image, publics, philosophy, positioning, perception and performance amid the rising need of a more favorable perception and reputation and to match the perception of customers, competitors and shareholders towards the university. In this study, four additional marketing mix will be introduced which are Partnership (PART), Publishing \& Conference (P\&C), Presentation (PRE) and Extracurricular Program (PROG) to determine the success factors influencing student admission into private colleges.

\subsubsection{Price (PRI) Factor in Private College Marketing Mix Strategy}

Price is the amount of money given in payment for something that may be bought or sold which in this case is the tuition and student fees. Prior researches have shown that price can be a major factor for potential students' decision to apply and enroll. A study by Stephen Wilkins over 320 of UAE students studying in an international branch found that avoiding financial expenses is one of the factors in making choice (Boehman, 2010). Lower tuition fees are extremely important determinant in their decision to study (Boehman, 2010). Cost of study varies by region, type of higher education institution and courses (Charles Darwin University, 2016). There are prestigious private colleges with best facilities charge high tuition fees to the student (Chartered Institute of Marketing (CIM), 2015).

\subsubsection{Place (PLA) Factor in Private College Marketing Mix Strategy}

Place is defined firstly as the location of the market where a private college will place its products and services in an attempt to gain market share and secondly the means of distribution where the delivery of the process of teaching a particular subject and interaction by a lecturer and the learning experience and activities which take place on the 
most feasible-cost-effective way. Interstates or branches located in a remote place where access to public phone, internet facility and shopping mall is limited, is for the students to apply for a remote placement near home. Shorter course periods and accommodation is also intended to attract students (Commission of Malaysian Law Reference, 2006). A study conducted by Wilkins et al found that there are several factors to select the location of a private college such as the number of expatriates in the area to tap for international student market segment, parent affordability, salary level, number of school leavers, and etcetera (Department of Statistic Malaysia, 2016).

\subsubsection{Product (PRO) Factor in Private College Marketing Mix Strategy}

Product refers to the academic products or study programs offered in the market for students to purchase. The outcome of college education makes student become educated, knowledgeable, mindful and skillful individuals who are able to understand and contribute to their career and the world around them. Universities worldwide have developed extremely different study programs and curricular design, concerning all fields and area of interest to satisfy the needs of higher education consumers (Emanuela, 2012). According to Hanover Research, students perceive or make value judgments about courses based on results, chance of gaining employment, internship, entrepreneurship, and etcetera (Goi and Goi, 2009; Mohd Yusob, et.al. 2015;Zhu, et al 2018).

\subsubsection{Promotion (PROM) Factor in Private College Marketing Mix Strategy}

Promotion in higher education is defined as all of the activities undertaken to communicate and promote its products to the target market encompassing all the selling tools including, advertising, personal selling, sales promotion, public relations and others or the combination of it (promotion mix) (Hanlon, 2014). According to Campus France, a French national agency for the promotion of higher education, international student service and international student mobility, 80 websites in 32 countries being used by student to apply for admission identify suitable programs and request entry visa have been maintained. It organizes international event that reaches an average of 160,000 visitors each year. According to a recent report by a communications agency Noir sur Blanc, $93 \%$ of the higher education institutions have already considered their institution to be a brand (Hanover Research, 2014).

\subsubsection{People (PEO) Factor in Private College Marketing Mix Strategy}

There are a wide range of people divided into curricular and extracurricular staff (rectors, deans, professors), managerial staff (student service staff, sales staff, managing director, to lower-qualified staff), business partners with university that provide financial support (alumni, ex-students, referral donors) and stakeholders (parents, law makers, society) (Jeyaraj, 2012). Prior researches show that the contribution of people and its impacts are a key success for higher educational institution enrolment. People influence in various ways such as giving a private college a positive image in the eyes of the students, thus affecting their perceptions and decisions. European academics agree that human actors who play parts in service delivery and in high contact with students are widely accepted as a new variable in the marketing mix (Zhao and Lan, 2017; Levin and Fox, 2006).

\subsubsection{Process (PROC) Factor in Private College Marketing Mix Strategy}

Academic and admission procedures are considered as the process factor in this study and vital factors to influence student application. A study by the Chartered Institute of Marketing found that user-friendly internet experience, good first impression, short waiting times, information given to student, the helpfulness of staff, fast and informative website and behavior of those who deliver, are crucial to ensure student satisfaction (Malaysia Qualification Agency (MQA), 2016). A study found that the process increases student assurance and confidence that they are buying from a reputable higher education institution or else they will tell their friends not to use the college's poor process (Stübinger, et al 2017; Ming, 2010).

\subsubsection{Physical Evidence (PE) Factor in Private College Marketing Mix Strategy}

Physical evidence is defined as the tangible cues or material components of the service which would be delivered (Ministry of Higher Learning Education (MOHE), 2015). Students rely on physical cues to help them evaluate a place to study before they decide because it is difficult to justify a high-quality education. In previous researches, there are many types of physical evidence cues found, used by higher education institutions to reinforce services such as physical environment (prestigious offices, scenic headquarters, and etc.), ambient conditions (temperature, color, smell, sound, music, noise etc.), spatial layout (way furniture or machinery is set up) functionality (how well-suited the environment to accomplish your needs) and signs, symbols and artefacts (packaging, brochures, signage, employee uniforms etc.) (Ministry of Higher Learning Education (MOHE), 2015 (Tat-Chee, 2015).

\subsubsection{Partnership (PART) Factor in Private College Marketing Mix Strategy}

Partnership can take various forms, partnership between two education institutions, public-private partnership or 
education institution-industry partnership, working with the best to promote its colleges. Previous studies found partnership competencies facilitate product differentiation, avoid keeping profit margins too low, create a high reputation, allow larger firms to leverage their own depth of resources and smaller firms to compensate for a lack of resources useful for firms in vulnerable strategic positions and powerful engine for innovation and economic growth (Ministry of Higher Learning Education (MOHE), 2015). Partners have bundles of resources, tradable and non-tradable ones, such as knowledge, social status, relationships, reputation, technology and trust on the market which are obviously not possible to acquire as these resources develop internally (Nedepour, 2014) (UiTM Integrity Unit, 2015).

\subsubsection{Publication and Conference (P\&C) Factor in Private College Marketing Mix Strategy}

Publishing is issuing academic researches or information available to people for sale or distribution. It is a part of the conference organized for researchers to present, discuss and exchange information on their work (Percetakan Nasional Berhad, 2012). A study conducted on the impact of Open Course Ware Publication (OCW) in Massachusetts Institute of Technology (MIT) found that 31\% of undergraduates, 30\% of graduates and $11 \%$ of freshmen described the OCW site's influence on their choice of place to study as very significant or significant, indicating that the site does help MIT to be more competitive in attracting students of all levels. Publications of students as authors inspire, increase enthusiasm and make them feel proud in their work. If students publish, they are likely seemed as established academics or informed professionals in their chosen fields of practice (Singh, et al 2018) (Sbaouelgi, 2017).

\subsubsection{Presentation (PRE) Factor in Private College Marketing Mix Strategy}

Presentation is accolades or recognitions given to institutions including staff, organization and student for their effort to pursuit excellence in diverse fields such as academics, athletics, research, entrepreneurship, and technology over the year (Zhang and Gao, 2018) (Senathip, et al 2017). A study on leaders from 202 higher education institutions (HEIs) in 41 countries on how ranking impact HEIs found that $50 \%$ of respondents felt it is a critical determinant for applicants, helps maintain and build institutional position, reputation and lucrativeness for the international market. Rankings are published by the media around the world and primarily for student reference. A plaque of commemoration, certificate and winning facilities are displayed on website benefiting the institution in the aspect of marketing (Setiyawati, et al 2018) (Singh, 2018).

\subsubsection{Extracurricular Program (EP) Factor in Private College Marketing Mix Strategy}

Extracurricular program is the activities that fall outside the realm of the normal curriculum of education or and pursued in addition to the normal course by students beyond the classroom in private colleges (Simpletuition, 2016). An online survey on over forty-eight Egyptian graduates studying on impact of extracurricular activities in Egyptian colleges on the job market found that $56 \%$ of the graduates agreed that the type of the extracurricular activity has an impact on the job market and a small percentage disagreed or chose to be neutral. Furthermore, $79 \%$ out of 48 participants agreed that the different positions in the extracurricular activities provide them with different skills. Also, $70 \%$ agreed that they learned soft skills from joining extracurricular activities (Singh and Issac, 2018) (Stavrou, 2018).

\subsection{Conceptual Research Model}

The theory used as an approach to marketing problems influencing student admission into private colleges is the Sales Performance Model. Student admission (Independent Variable) is explained by the marketing strategy (Dependent Variable). The underpinning theories form dependent variables are 11 Ps Extended Marketing Mix Theory (Wilkins, et al 2012). 


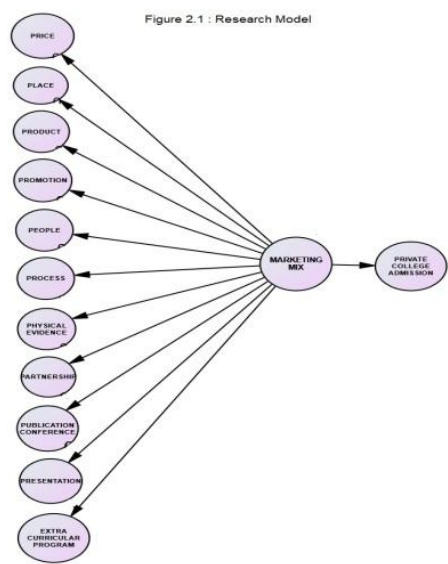

Figure 1. Research model

\section{Research Methodology}

This study implemented a conclusive research design by using the quantitative research method. It composes of the structuring fieldwork and the sampling design. Structuring fieldwork specifies types and sources of data, techniques to obtain data to address the research problem, objectives and also hypotheses. The types of data used are primary and secondary data. It is used to better refine the problem, develop the approach to the problem and strengthen the findings. The secondary data sources are computerized database and published secondary data. The primary data collection method is e-mail survey questionnaire. It was administered to the marketing manager of the private colleges as the respondents. Sampling design is the framework in defining and selecting the sample. The sample size of this study is 366 . The sampling method used is probability sampling, a typical area sampling technique (Zainal, et al 2012).

\section{Results and Findings}

\subsection{The Success Factors Influencing Marketing Strategy of Private Colleges}

Marketing mix is widely used as strategy in attracting students to study in higher education institutions. Private college has not been conducting the study on the marketing success factor s amid the rising importance in boosting student admission growth and attracting international students to study in national private colleges. In this study, 11 Ps are the success factors influencing private college's marketing mix strategy in influencing students to study in private colleges.

Pooled Second-Order Confirmatory Factor Analysis (PCFA) is conducted to validate of the measurement model and there were few items deletion and modification. All of the requirement of CFA namely, fitness index, unidimensionality, reliability and validity of measurement model fulfilled. According to Hair (2012) at least one fitness index from each category of model fit use in validating the model. According to the table Figure 4.1 in upper right, Good Fit Index (GFI) and Tucker Lewis Index (TLI) score which are 0.953 and 0.932 respectively are above the leel of acceptence point $>0.90$ and Chisq/df score is 2.332 below the minimum cut off point < 3.0. Unidimensionality of the measurement model is achieved when items measuring the subconstruct and construct obtain factor loadings in the range of 0.538 to 1.00. According to Zainudding Awang (2014) acceptable factor loadings for every item should be 0.5 or higher. Validity requirement is achieved when all of the validity assessments of Convergent Validity, Construct Validity and Discriminant Validity meet the acceptance level. Convergent Validity requirement is achieved when AVE score for every construct and subconstruct is in the range of 0.5 to 1.00 above the acceptance level 0.5 indicating all items in a measurement model are statistically significant. Construct Validity requirement is achieved when all of the fitness indexes meet required level. Discriminat Validity requirement is also achieved when the measurement model of a construct is free from redundant items indicated by Modification Index (M.I) which in range of 1.37 to 15.00 equal and below acceptance level of 15.0 which above consider high. 


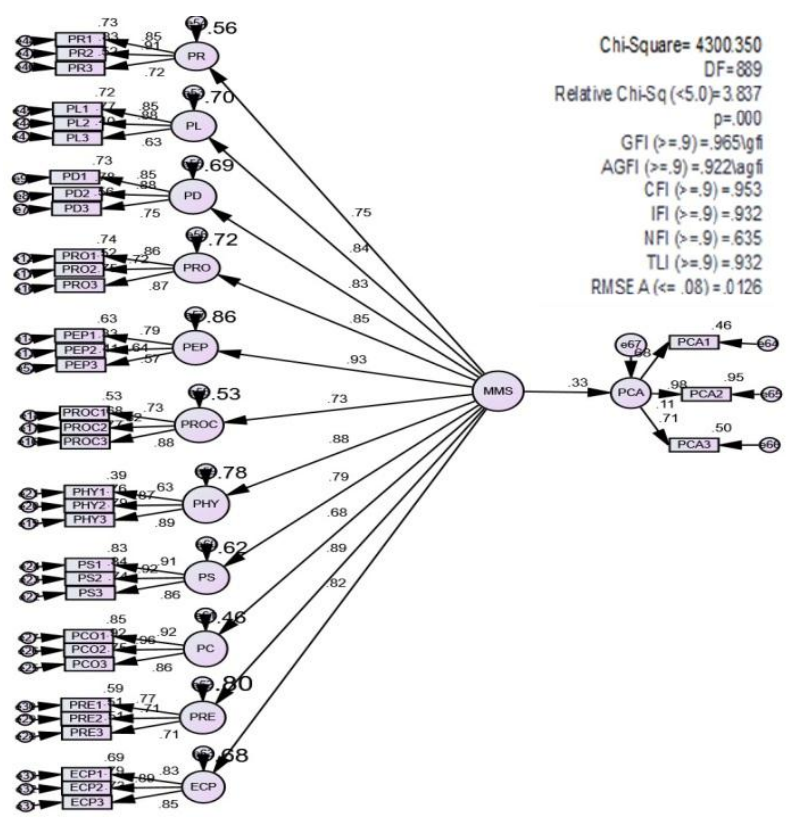

Figure 2. Standardized estimate of research model

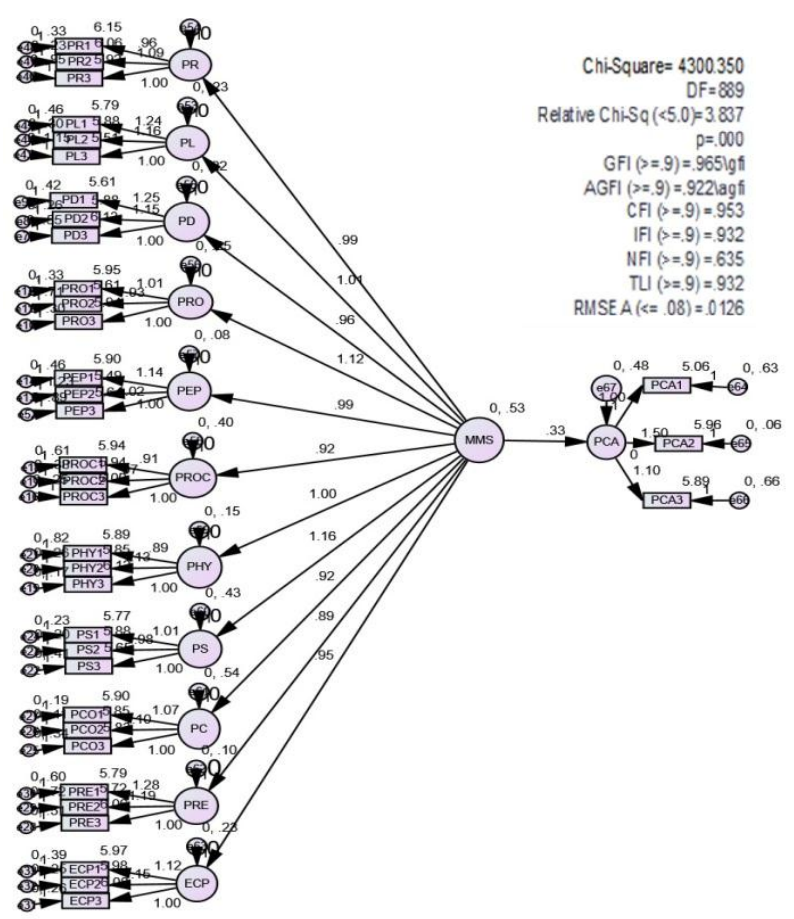

Figure 3. Unstandardized estimate of research model

Table 1. Unstandardized, standardized and significance levels for structural equation model

\begin{tabular}{|c|c|c|c|c|c|c|}
\hline Construct & & Subconstruct & $\mathrm{R} 2$ & $\begin{array}{l}\text { Standarized } \\
\text { Estimate }\end{array}$ & $\begin{array}{l}\text { Unstandardized } \\
\text { Estimate }\end{array}$ & $\mathrm{P}$ \\
\hline MMS & $<---$ & PD & 0.694 & 0.833 & 0.961 & $.000 *$ \\
\hline MMS & $<---$ & PRO & 0.722 & 0.850 & 1.119 & $.000 *$ \\
\hline
\end{tabular}




\begin{tabular}{|c|c|c|c|c|c|c|}
\hline MMS & $<---$ & PEP & 0.863 & 0.929 & 0.995 & $.000 *$ \\
\hline MMS & $<--$ & PROC & 0.528 & 0.726 & 0.919 & $.000 *$ \\
\hline MMS & $<--$ & PHY & 0.783 & 0.885 & 1 & $.000 *$ \\
\hline MMS & $<---$ & PL & 0.701 & 0.837 & 1.012 & $.000^{*}$ \\
\hline MMS & $<---$ & PS & 0.621 & 0.788 & 1.158 & $.000 *$ \\
\hline MMS & $<---$ & $\mathrm{PCO}$ & 0.456 & 0.675 & 0.924 & $.000 *$ \\
\hline MMS & $<---$ & PRE & 0.801 & 0.895 & 0.893 & $.000 *$ \\
\hline MMS & $<---$ & ECP & 0.676 & 0.822 & 0.947 & $.000 *$ \\
\hline MMS & $<---$ & PR & 0.555 & 0.745 & 0.992 & $.000 *$ \\
\hline MMS & $<---$ & PCA & 0.109 & 0.333 & 0.333 & $.000 *$ \\
\hline Subconstruct & & Items & & & & \\
\hline PD & $<---$ & PD3 & 0.726 & 0.75 & 1 & $.000 *$ \\
\hline PD & $<---$ & PD2 & 0.781 & 0.884 & 1.149 & $.000 *$ \\
\hline PD & $<---$ & PD1 & 0.563 & 0.852 & 1.251 & $.000 *$ \\
\hline PRO & $<---$ & PRO3 & 0.742 & 0.868 & 1 & $.000 *$ \\
\hline PRO & $<---$ & $\mathrm{PRO} 2$ & 0.524 & 0.724 & 0.927 & $.000 *$ \\
\hline PRO & $<---$ & PRO1 & 0.754 & 0.861 & 1.012 & $.000 *$ \\
\hline PEP & $<---$ & PEP3 & 0.415 & 0.574 & 1 & $.000 *$ \\
\hline PEP & $<---$ & PEP2 & 0.329 & 0.574 & 1 & $.000 *$ \\
\hline PEP & $<---$ & PEP1 & 0.629 & 0.793 & 1.135 & $.000 *$ \\
\hline PROC & $<---$ & PROC3 & 0.773 & 0.879 & 1 & $.000 *$ \\
\hline PROC & $<---$ & PROC2 & 0.675 & 0.822 & 0.97 & $.000 *$ \\
\hline PROC & $<---$ & PROC1 & 0.534 & 0.731 & 0.914 & $.000 *$ \\
\hline PHY & $<---$ & PHY3 & 0.794 & 0.891 & 1 & $.000 *$ \\
\hline PHY & $<---$ & PHY2 & 0.765 & 0.874 & 1.126 & $.000 *$ \\
\hline PHY & & PHY1 & 0.392 & 0.626 & 0.885 & $.000 *$ \\
\hline PS & $<---$ & PS3 & 0.737 & 0.626 & 0.885 & $.000 *$ \\
\hline PS & $<---$ & PS2 & 0.845 & 0.858 & 1 & $.000 *$ \\
\hline PS & $<---$ & PS1 & 0.834 & 0.919 & 0.979 & $.000 *$ \\
\hline $\mathrm{PC}$ & $<---$ & PCO3 & 0.854 & 0.913 & 1.014 & $.000 *$ \\
\hline PC & $<---$ & $\mathrm{PCO} 2$ & 0.918 & 0.864 & 1 & $.000 *$ \\
\hline PC & $<---$ & PCO1 & 0.85 & 0.958 & 1.097 & $.000 *$ \\
\hline PRE & $<---$ & PRE3 & 0.51 & 0.924 & 1.072 & $.000 *$ \\
\hline PRE & $<---$ & PRE2 & 0.509 & 0.714 & 1 & $.000 *$ \\
\hline PRE & $<---$ & PRE1 & 0.592 & 0.713 & 1.192 & $.000 *$ \\
\hline ECP & $<---$ & ECP3 & 0.729 & 0.769 & 1.282 & $.000 *$ \\
\hline ECP & $<---$ & $\mathrm{ECP} 2$ & 0.786 & 0.854 & 1 & $.000 *$ \\
\hline ECP & $<---$ & ECP1 & 0.694 & 0.887 & 1.149 & $.000 *$ \\
\hline PL & $<---$ & PL3 & 0.402 & 0.634 & 1 & $.000 *$ \\
\hline PL & $<---$ & PL2 & 0.774 & 0.88 & 1.156 & $.000 *$ \\
\hline PL & $<---$ & PL1 & 0.722 & 0.85 & 1.238 & $.000 *$ \\
\hline
\end{tabular}




\begin{tabular}{lllllll} 
PR & $<---$ & PR3 & 0.523 & 0.88 & 1.156 & $.000^{*}$ \\
PR & $<--$ & PR2 & 0.831 & 0.85 & 1.238 & $.000^{*}$ \\
PR & $<---$ & PR1 & 0.728 & 0.724 & 1 & $.000^{*}$ \\
PCA & $<---$ & PCA3 & 0.499 & 0.911 & 1.09 & $.000^{*}$ \\
PCA & $<---$ & PCA2 & 0.953 & 0.853 & 0.965 & $.000^{*}$ \\
PCA & $<---$ & PCA1 & 0.46 & 0.644 & 1.018 & $.000^{*}$ \\
\hline
\end{tabular}

Table 2 shows the result of Structural Equation Model (SEM), based on the Standardized Estimate table, the result shows factors loading of Second Order Factor of Marketing Mix on its sub-construct. The strongest is People for 0.929, followed by Presentation (0.895), Physical Evidence (0.885), Promotion (0.850), Place (0.837), Product (0.833), Extra Curricular Program (0.822), Partnership (0.788), Price (0.745), Process (0.726) and Publication and Conference (0.675). The strength of the relationship is in range of 0.9-0.6 which indicates a perfect or strong relationship. According to $\mathrm{R}^{2}$ score, the subconstructs or in other words the factors with the highest percentage of variation in contributing to the Marketing Mix Strategy are People for $86 \%$, followed by Presentation $801 \%$, Physical Evidence 783\%, Promotion 72\%, Place 70\%, Product 69\%, Extra Curricular Program 67\%, Partnership 62\%, Price 55\%, Process 52\% and Publication and Conference 45\%. Table of Unstandardized Estimate, shows the regression coefficient of the Marketing Mix Strategy on all of the subconstructs. According to the table, p-values of Price, Place, Product, Promotion, People, Process, Physical Evidence and Publication and Conference are highly significant since their respective values are 0.00 .

It also found that factor loading of Marketing Mix on Private College Admission is 0.333 indicating a weak relationship. $\mathrm{R}^{2}$ score 0.109 indicate the amount of variance explain in Private College Admission by Marketing Mix is only $10 \%$. It means there are other factors could contribute to the admission need to conduct further study. The relationship between Marketing Mix on Private College Admission is also significant $(p<0.05)$. Thus it can be concluded that there is a significant relationship between the marketing success factors with the Marketing Mix Strategy of private colleges. The findings also found that the Marketing Mix Strategy has a significant relationship with Private College Admission addressing all of the objectives is in Table 4.3 below.

Table 2. The hypothesis statement and its conclusion

\begin{tabular}{lll}
\hline Hypothesis Statement & Decision \\
\hline H1 & Price has a positive and significant relationship with Marketing Strategy & Supported \\
H2 & Place has a positive and significant relationship with Marketing Strategy & Supported \\
H3 & Product has a positive and significant relationship with Marketing Strategy & Supported \\
H4 & Promotion has a positive and significant relationship with Marketing Strategy & Supported \\
H5 & People has a positive and significant relationship with Marketing Strategy & Supported \\
H6 & Process has a positive and significant relationship with Marketing Strategy & Supported \\
H7 & Physical Evidence has a positive and significant relationship with Marketing Strategy & Supported \\
H8 & Partnership has a positive and significant relationship with Marketing Strategy & Supported \\
H9 & Publication and Conference has a positive and significant relationship with Marketing & Supported \\
H10 & Strategy & \\
H11 & Extra-Curricular Program has a positive and significant relationship with Marketing & Supported \\
H12 & Strategy & Marketing Mix has significant relationship with Private College Admission \\
\hline
\end{tabular}

\section{Conclusion}

In conclusion, this study aims to find solutions to the problems faced by private colleges. Private colleges harnessing 
their full potential and the marketing strategy in pursuit of maximizing the local and international student admission. It is lacking sustainable and competitive business model in which does not improve student admission result. The findings of the study show that the 11Ps as the factors which have a significant relationship with marketing mix strategy are Price, Place, Product, Promotion, People, Process, Physical Evidence, Partnership, Publication and Conference, Presentation and Extra-Curricular Program. It successfully addressed the research objective of answering what are the success factors influencing the marketing mix strategy. The findings successfully addressed the research objective which is to determine the significant relationship between the marketing mix and private college admission. It points out a specific set of capabilities, information sources, decision styles, strategies, and attitudes required towards creating sustainable competitive advantages in private colleges. Theoretically, this study introduces a new construct into the 7Ps of Marketing Mix Theory in the marketing aspect of the higher education.

\section{References}

Abdul Rahman, M. A. (2010). Malaysia: Models in private higher education. University World News. Retrieved from http://www.universityworldnews.com/article.php

Asia Exchange. (2016). Study in Kuala Lumpur. Asia's Emerging Education Hub. Retrieved from http://www.asiaexchange.org/study-abroad/study-abroad-in-malaysia

Awang, A. H., Ramli, Z., \& Ibrahim, I. (2012). Attraction Factors of International Graduate Students to Research Universities in Malaysia. Malaysia Journal of Society and Space, 8(6), 32-41. Retrieved from http://www.ukm.my /geografia /images/ upload/pdf

Beiler, P. (2014). What is the Difference Between a College and a University?. Retrieved from http://www.bestvalueschools.com

Boehman. (2010). Student Development Theory. Retrieved from https://facultystaff.richmond.edu/ jboehman/sdt.pdf

Charles Darwin University. (2016). Remote Placements. Charles Darwin School of Health. Retrieved from http://www.cdu.au/health/remote-placements

Chartered Institute of Marketing (CIM). (2015). A Brief Summary of Marketing and How It Works. Retrieved from https://www.cim.co.uk/files/7ps.pdf

Commission of Malaysian Law Reference. (2006). Akta 30 Akta Universiti dan Kolej Universiti 1971. Retrieved from http://www.uthm.edu.my/v2/images/info/auku.pdf

Department of Statistic Malaysia. (2016). Perak Statistic [Data File]. Retrieved from https://www.statistics.gov.my/index

Emanuela, M. (2012). Higher Education Student Choice Influencing Factors. Holistic Marketing Management Journal, Holistic Marketing Management, 2(2), 59-64. Retrieved from https://ideas.repec.org/a/hmm/journl/v2y2012i2p59-64.html

Goi, C. L., \& Goi, M. T. (2009). Rebranding of Higher Educational Institutions in Malaysia. Journal in International Journal of Business and Management, 4(9). http://dx.doi.org/10.5539/ijbm.v4n9p170

Hanlon, A. (2014). How to Use the 7P's Marketing Mix?. Retrieved from http://www.smartinsights.com

Hanover Research. (2014). Trends in Higher Education Marketing, Recruitment, and Technology. Retrieved from http://www.hanoverresearch.com/media/

Jeyaraj, A. (2012, April 1). Tertiary Education in Perak [web log comment]. Retrieved from http://www.ipohecho.com.my/v2/2012/04/01/tertiary-education-inperak

Levin, J., \& Fox, J. A. (2006). Tenth Edition Elementary Statistic in Social Research. Boston, Massachusetts: Pearson.

Malaysia Qualification Agency (MQA). (2016). Malaysia Qualification Agency [Data File]. Retrieved from http://www.mqa.gov.my/mqr/akrbyipta.cfm

Ming, J. S. K. (2010). Institutional Factors Influencing Students' College Choice Decision in Malaysia: A Conceptual Framework. Journal in International Journal of Business and Social Science, 1(3). Retrieved from http://www.ijbssnet.com /journals/Vol._1_No._3_December_2010/6.pdf

Ministry of Higher Learning Education (MOHE). (2015). Executive Summary of Malaysia Education Blueprint 2015-2025 (Higher Education). Retrieved https://www.um.edu.my/docs/default-source/about-um_document/media-centre/um-magazine/4-executive 
Ministry of Higher Learning Education (MOHE). (2015). Malaysia Higher Education Indicator 2011-2012 [Data File]. Retrieved from http://www.mohe.gov.my/web_statistik/Indikator_PT-20112012.pdf

Ministry of Higher Learning Education (MOHE). (2015). The Malaysian Higher Education System - An Overview. Retrieved from https://www.studymalaysia.com

Mohd Yusob, M. L., Salleh, M. A., Haron, A. S., Makhtar, M., Asari, K. N., \& Jamil, L. S. M. (2015). Maqasid al-Shariah as a Parameter for Islamic Countries in Screening International Treaties before Ratification: An Analysis. Pertanika Journal of Social Sciences \& Humanities, $23: 219-226$

Nedepour, K. (2014). Innovative and Marketing Strategies. Journal in GIMAC5 5th Global Islamic Marketing Conference, 633-635.

Percetakan Nasional Berhad. (2012). Akta A1352 Akta Institusi Pendidikan Tinggi Swasta (Pindaan) 2012. Retrieved from http://www.federalgazette.agc.gov.my/outputaktap/.pdf

Sbaouelgi, J. (2017). Income Inequality and Economic Growth: Application of Quantile Regression. Asian Development Policy Review, 6(1), 1-14. https://doi.org/10.18488/journal.107.2018.61.1.14

Senathip, T., Mujtaba, B. G., \& Cavico, F. J. (2017). Policy-Making Considerations for Ethical and Sustainable Economic Development. Economy, 4(1), 7-14. https://doi.org/10.20448/journal.502.2017.41.7.14

Setiyawati, H., Iskandar, D., \& Basar, Y. S. (2018). The Quality of Financial Reporting through Increasing the Competence of Internal Accountants and Accrual Basis. International Journal of Economics, Business and Management Studies, 5(1), 31-40. https://doi.org/10.20448/802.51.31.39

Simpletuition. (2016). The Cost of Attendance. Retrieved from http://www.simpletuition.com/financial-aid/what-is-the-cost-of-attend

Singh, A. K., \& Issac, J. (2018). Impact of Climatic and Non-climatic Factors on Sustainable Livelihood Security in Gujarat State of India: A Statistical Exploration. Agriculture and Food Sciences Research, 5(1), 30-46. https://doi.org/10.20448/journal.512.2018.51.30.46

Singh, H. S. I., Hussein, S. B. M., \& Dahlan, N. K. B. (2018). The Api-Api Constructive Trust Test: Coming Out of the Murky Into Dangerous Waters?. International Journal of Asian Social Science, 8(11), 1068-1076. https://doi.org/10.18488/journal.1.2018.811.1068.1076

Singh, R. (2018). Perspectives on India-Bangladesh Water Dispute: The Farakka Barrage. Asian Themes in Social Sciences Research, 1(1), 14-20. https://doi.org/10.33094/journal.139.2018.11.14.20

Stavrou, P. D. (2018). Psychoanalytic Psychotherapy as a Treatment for Depression in Adolescents: A Case Study. Global Journal of Social Sciences Studies, 4(2), 91-101. https://doi.org/10.20448/807.4.2.91.101

Stübinger, J., Walter, D., \& Knoll, J. (2017). Financial market predictions with Factorization Machines: Trading the opening hour based on overnight social media data (No. 19/2017). FAU Discussion Papers in Economics.

Tat-Chee, W. (2015). Evolution of Tertiary Education in Malaysia [PDF document]. Retrieved from http://www.iie.org/ /media/Files/Corporate/G8

UiTM Integrity Unit. (2015). Akta Universiti Teknologi MARA 1976 (Akta 173) [Powerpoint slide]. Retrieved from $\mathrm{http}: / / \mathrm{km}$.ptar.uitm.edu.my/documents

Wilkins, S., Balakrishnan, M. S., \& Huisman, J. (2012). Student choice in higher education: Motivations for choosing to study at an international branch campus. Journal of Studies in International Education, 16(5), 413-433.

Zainal, A., Mohd Radzi, S., Hashim R., Tamby Chik, C., \& Abu, R. (2012). Proceedings from IHTC 2012: The International Hospitality and Tourism Conference. https://doi.org/10.1201/b12752

Zhang, K., \& Gao, J. (2018). Coordination Strategy of Dual-Channel Supply Chain for Fresh Product Under the Fresh-Keeping Efforts. International Journal of Emerging Trends in Social Sciences, 4(2), 75-85. https://doi.org/10.20448/2001.42.75.85

Zhao, X., \& Lan, P. (2017). How Chinese State-Owned Enterprises Change Their Dynamics in New Product Innovation?. Asian Journal of Economics and Empirical Research, 4(1), 25-31. https://doi.org/10.20448/journal.501.2017.41.25.31

Zhu, Y., Ge, J., Wang, X., \& Xu, Z. (2018). Feature Analysis of Ship Emission Under China's ECA Policy: A Perspective from Shanghai. International Journal of Management and Sustainability, 7(3), 143-155. 